\title{
School Leadership in Pre-University Albanian Education System (1995-2012): Politics, Issues and Trends
}

\author{
Valbona Nathanaili \\ Publishing Director, European University of Tirana; Email valbona.nathanaili@uet.edu.al
}

Doi:10.5901/jesr.2015.v5n3p201

\section{Abstract}

\begin{abstract}
The job of the school leader is becoming very difficult. During a working day, he has to face a variety of challenges and to find solutions for many problems of all kinds. The concerns and interests of parents, teachers and district administration do not always coincide. (Johnson, 1976: 80). On the other hand, public schools do not select the pupils who will attend. (Ibid) The children community in school is growing diverse due to their family origins which have different and unique structures, and to demographic movements. A diverse community represents diverse demands. The school leader shall be the manager and the teacher, the planner and the implementer, the school advocate and its critique, so as to be committed and able to perform its responsibilities (Pierce \& Stapleton, 2002), comply with the requirements of DAR and MAS and find the right balance between different stakeholders. There are many complex roles a leader shall take which means assuming many accountability, however, not always justified by the salary. But, our main concern is to save the public schools, and in order to be able to compile such a mission, we need a new kind of leadership, visionary, able to understand what will happen to school at 5 to 10 years following, to identify problems and to know how to respond the needs in change of the community (Pierce \& Stapleton, 2002). This essay is a review of key issues, trends and current policy in Albanian school leadership at pre-university education system during 1995-2012.
\end{abstract}

Keywords: school leadership, policy, practice, criteria.

\section{Introduction}

Reforms in education doesn't last more than the mandate of policymaker (Elmore, 2004). The political influence in the Albanian education system has been present and ongoing for a long time, affecting therefore the formal and informal concept of a school leadership.

After the '90s, it should be noted how much efforts has been made to change schools. An increasing number of undertaken reforms are relating with educational practices in response of new demands for accountability and quality, teacher professional development, curricula, textbooks, technological innovations and their use in classes, the performance of students and the skills required to challenge job market, etc.

The following is a brief summary of the mission and duties appointed on the leading authorities in the field of education by the law no. 7952, dated 21.06.1995 "On pre-university education system" in Albania. This Law was in force until 2012.

\section{Leading Educational Authorities in Albania, the Pyramid (Until 2012). A Brief Summary Based on Legislation}

At the national level: The Council of Ministers, Ministry of Education and Science (MASH).

The Council of Ministers designs the general national policies, approves the national strategy of pre-university education and sets criteria for including children in need in financial assistance schemes.

Ministry of Education and Science (MASH) is the highest administrative public authority in the field of education. MASH is in charge, through others, to design the national strategy of pre-university education system, compile and elaborate teaching plans and curricula for the development of education through its specialists and its subsidiary institutions in conformity with international trends and national, regional, social-economic and demographic peculiarities of Albania, etc.

At the local level: The basic unit on the local government, Regional Educational Directory (DAR) or Educational Office (ZA).

The basic unit on the local government duties relate to the provision of public educational institutions 
infrastructure, and support with funding for: extra salary, financial aid for students in need, awards for gifted students, training of educational institutions staff and curriculum development by choice.

Regional Educational Directory (DAR) or Educational Office (ZA), whose director is appointed or dismissed by a decision of the Minister of Education and Science, under the procedures established by legal acts issued by it (see below).

At the school level: School Leadership, Deputy Director, School Board, Pedagogical council, Subject team and Student Government.

\section{External exceptions for school leadership}

The mission of school leadership is to guide the activities of the institution, in order to continuously improve the quality of education service for all students, to ensure implementation of the law at school level, to respect standards leadership, to guide the design and implementation of semester and annual institution plan in cooperation with the school board, faculty council, parents, local educational unit (DAR/AZ) and the local government unit, to provide periodical assessment of student achievement and school self-evaluation, to guide pedagogical council, and to encourage and provide professional development to school; to perform annual assessment work for all school employees.

The school director is appointed by the Regional Education Directorate (DAR) based on competition. Leadership directs, at school, the learning, administrative and financial processes.

The translation of external expectations into internal meaning (from school inside)

The central figure of the school is its leader, known as the principal. The leader is considered the highest authority in the school to resolve any conflict; he must possess a range of skills, categorized as technical, personal and managerial. With regards to the leadership at school level, there are many other organizational structures designed to support the work of the leader and to successfully achieve the school's mission, but the engagement's quantity and quality of these actors is mostly a product of the leadership style that the school leader has chosen to apply.

Not only does it vary from area to area, but also, often, within the same area. The success of a certain style comes as a result of personal leadership initiatives, disregarding the guidelines of the system, which in fact are missing to a great extent.

The leader may exercise control at class level and holds the right to make an annual assessment of the teacher's performance which gives him a formal authority over the teaching staff. On the other hand, it is almost impossible for the leader to dismiss an incompetent teacher or such a mission requires extensive efforts and DAR proceedings, which often are forced to end up without an effective resolution.

This drawback can be compensated, however, by way of a good leadership and communication skills so as to create the necessary climate of cooperation and improvement (when necessary).

Generally, it has been noted a lack of ambition among old teachers to assume the role of the leader. Their participation in the qualifications offered by the government or the ones they personally select are of an academic background, usually in function of professional preparation and acquiring teaching materials. A career in the Albanian education system is very limited and doesn't offer wide possibilities: it starts as a teacher and can end (or not) as a principal. This career perspective evidences the presence of two more negative sides of it: firstly, the leader is not dynamic and then its job falls into a normal working routine; secondly, considering that there are few leaders only in a large group of teachers, most teachers are hold back by such competition and do not aim at being in charge of the school, which translates in a lack of daily engagement to the success of the school as a whole and in the encouragement of the isolated-teacher model surrounded by the classroom walls only.

Furthermore, it is necessary to develop structures which will make the leadership role more attractive and flexible and, at the same time, it will set higher leadership standards.

In some cases, the leadership is a product of political circumstances. The missing key competences in such cases are technical, resulting in a disability to adapt the teaching programme to local needs and to engage in teacher monitoring, evaluation and professional development.

The legislation encourages the concept of distributed and collective leadership, as well as the cooperation with a great number of actors to successfully implement this concept, but it is limited only to definitions.

The culture of individual leadership and a lack in conceptualization of practices of distributed leadership are obstacles which have to be taken in consideration. In general, the interchange and influence range of the leadership is limited: it starts and ends usually at the school's boundaries (as a building and social structure). The model of isolated teachers is mirrored in the model of isolated leadership. There is a lack in formal and informal networks of leadership. The success of a part rarely becomes the success of the whole, restricting in such way, the propagation and dissemination of successful initiatives or improvement at the large-scale. 
Because Albania is a Balkan country, there is a stereotypical perception of leadership concept: individual leadership, who has difficulty to share (especially when speaking about success) and large inertia in decisions (i.e. lack of flexibility). By taking forward this traditional concept, more

sensitive features becomes visible to high schools and large schools with high number of students and teachers and less visible in primary schools and small schools (again in terms of number students and teachers).

Finally, social (informal) ties between school leader-teachers are generally weak. Often teachers do not feel comfortable in the presence of the school leader. Furthermore, in Albanian public schools, the teacher is free to leave the school immediately following the end of the class (until the end of 2010).

Responsibility is fragmented and centralized, meaning that teachers respond for their classes and leaders for the whole school. For these reasons, in order to achieve a collective leadership model, I think that still a long path awaits us ahead.

\section{School Leaders/School Leadership: Recruitment}

Based upon bylaws passed in accordance with law No. 7952, the Minister of Education and Science has the authority to hire or dismiss the Regional Educational Directory leader (DAR) or Educational Office leader (ZA's). In the case of the school leaders, the policies for hiring or dismissing them vary on the applicable formally designed procedures and criteria.

So, with regards to public schools, DAR leaders have such power, whereas as per private school, the selective criteria and dismissing procedures are subject to the internal institution rules.

However, despite the established authority responsible for selecting the school leaders, there are some formal minimum requirements to be met for candidates which are almost identical in both types of institutions (public or private), such as: the candidate shall hold a university degree in the field of education and other qualifications and he should have teaching experience. But due to the competition between these two sectors of education, private schools, in order to gain popularity, tend to invest more resources in recruiting qualified leaders and embrace higher standards of quality. The following example is a school leader job vacancy advertisement at "Hermann Gmeiner", an elementary school. The advert was published in the newspaper and it contained followed by the required criteria:

The school director of SOS Hermann Gmeiner directs and manages the daily activities of SOS school.

Criteria required:

- Degree in teaching in 8-year education cycle (preferably masters degree in the field of education/ management);

- Have at least 5 years experience as a director and at least 15 years of teaching experience;

- Knowledge on contemporary teaching methods and pedagogical work with children.

- Skills in managing human resources;

- Good interpersonal skills of oral and written communication;

- Ability to work under pressure;

- Ability to work in groups and independently;

- Ability to analyze and evaluate situations and to take actions for protecting the children;

- Motivation, commitment, flexibility;

- Good knowledge of English;

The following table (Table I) is a summary of key qualified requirements for school leadership compared with DAR leadership requirements.

The selection criteria are based on Law No. 7952 on "Pre-university education system" and bylaws issued in accordance with it:

Table I. Summary of key qualified requirements for school leadership compared with DAR leadership requirements.

\begin{tabular}{|l|l|}
\hline School leader - selection & DAR leader -selection \\
\hline With formal competition (organized by DAR/ZA) & With open formal competition (organized by MASH) \\
\hline Without mandate (employment contract) & With status of servant service \\
$\begin{array}{l}\text { Elected among teachers (professional) } \\
\text { (teacher-assistant leader - school leader) applies }\end{array}$ & $\begin{array}{l}\text { Elected among school leaders (professional) } \\
\text { Usually traditional scheme of carrier are followed: teacher - school leader- DAR } \\
\text { occasionally }\end{array}$ \\
\hline
\end{tabular}




\begin{tabular}{|c|c|}
\hline $\begin{array}{l}\text { Informal criteria: It is often perceived as political position; } \\
\text { individual initiatives is necessary from persons who aspirate } \\
\text { to be school leader; other peer network. }\end{array}$ & $\begin{array}{l}\text { Informal criteria: It is perceived as political position: rotates together with the } \\
\text { government changes accompanied by the change of DAR leaders itself. }\end{array}$ \\
\hline $\begin{array}{l}\text { Formal criteria: university degree (master in } \\
\text { management/administrative education is a priority); } \\
\text { qualifications; long teaching experience. }\end{array}$ & 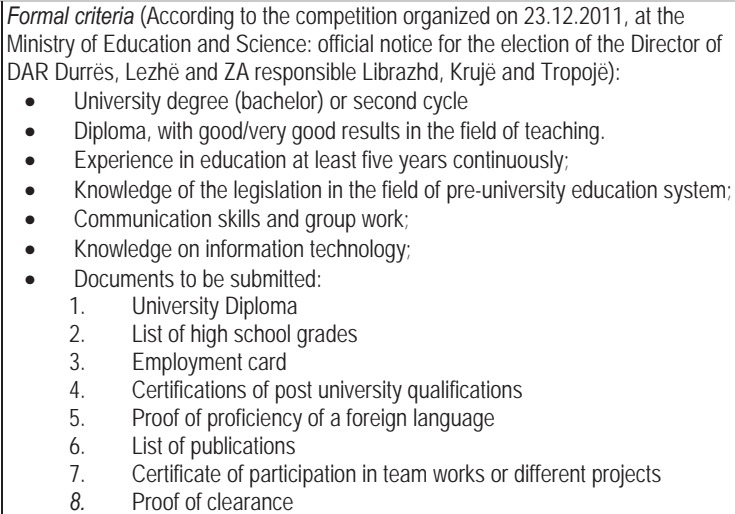 \\
\hline
\end{tabular}

As seen from the table, Law No. 7952 "On pre-university education system" and the bylaws issued in accordance with it do not contain clear criteria for selecting the school leadership. Those criteria are determined by DAR (ZA), which are not always transparent or accessible to all; it should be noted that, in general, it doesn't exist any clear policy to identify and recruit candidates among the teachers, nor to recognize professionals with strong leadership potential for the future. The common perceiving of the teaching profession is that it does not offer career opportunities.

\section{School Leaders/School Leadership: Preparation and Development}

The year period 1995-2010 is characterized by an apparent lack of investments in leadership preparation and development. A significant role for training school leader is played by various national and international nongovernmental agencies operating in Albania, which organize through different projects workshops for school management.

Unfortunately, they are uncoordinated at the national level. Trainings are often offered outside the school building and are unrelated to the real problems the schools face. Therefore, it should be done more to improve the CVs of school leaders which would improve directly the school environment. However, such programs shall be welcomed in all those schools which have become part of their initiatives.

We have to note, too, the role of Ministry of Education and Science, together with its subsidiary institutions in compiling and developing policies and strategies for school leadership: DAR, the Institute of Pedagogical Research, the Institute for Educational Development (IZHA), the Department of pre-university education, the unit responsible for human resources policies in MASH and training centers for education and training (the latter is created with the help of World Bank).

But, the Ministry of Education and Science has not drawn up a long-term plan related to the development of school leadership, nor did it list priorities in this regard. Little effort has been made to develop human and social capital. Additionally, the lack of a coherent and comprehensive method to select talented staff and the insufficient training funds have contributed together in the diminishing the quality of school leaders and increasing the number of unqualified school leaders who run a school.

Selecting school leaders who will participate in training is usually a competence of DAR. The issued covered therein are generally related to: curricula, teaching by focusing on the student, methods to develop a critical thinking, teaching methods, evaluation and self-evaluation, planning, decentralization, legislation, child abuse, human and children rights, communication, school conduct and management etc.

Example: Modules program for training school leaders in the pre-university education system:

1. Main theories and practices of managing the institution;

2. The applicable legislation for conducting and managing the institution.

3. The leader's role in the pedagogical development and curriculum management.

4. Institution development plans;

5. Cooperation strategies with community representatives and governmental or non-governmental partners. 
6. Communication, ethics and technology.

\section{School Leaders/School Leadership: The Current Changes that have been Made in Relation to}

According to the Directive no. 5310 / 2, dt. 12.10.201, issued by the Secretary General of Ministry of Education, Mr.Skënder Uka, a program is set up which adopts the belief that the institution's direction and management shall not be left to the chance. School leadership should be set up professionally, at the expert level of leadership and management. The purpose of this program is to help the current leaders and those who aspire to lead an institution, to meet the best standards of a leader.

The Directive Nr.7170, dated 22.11.2010 "On qualification of preschool and school leaders" of the Ministry of Education and Science, states that qualification procedures for leaders in public and private pre-school and school institutions shall be developed in compliance with the Regulation "On qualification of leaders in pre-school and school institutions". Current school leaders and aspiring ones are subject to this Directive. According to the Directive, in order to be considered as a school leader candidate in a pre-university institution, one shall obtain the "Leader Certificate" (Table II).

This certificate may be obtained in the way described as follows:

Table II. Leader Certificate (Valid for 8 years).

\begin{tabular}{|l}
\hline \multicolumn{1}{|l|}{ THE FINAL QUALIFICATION TEST [the assessment is based on bonuses (10 \% of total points are awarded when holding one of these degrees: } \\
SHPU, MND, MSc, professional master, PhD and a foreign language qualification) and on test results (90\% of total points)]
\end{tabular}

According to the MASH website (2012), "The national program for leaders qualification" aims to teach to the participants the knowledge, practices and necessary competences to perform the duty of the leader in compliance with contemporary successful principals and practices. The main object of the program is to increase competences at a national level and develop school management materials. The program author is IZHA, in collaboration with the "School of Educational Management" in the Netherlands, 2010-2012.

\section{Actors and Agencies that Support the Policies and the Implementation of School Leadership}

Agencies which monitor the policies for leadership implementation are MASH and its subsidiaries, DAR and ZA.

To a certain extent, DAR has some freedom degrees to implement the national strategy for education, but always within the boundaries of its zone of jurisdiction. Periodic meetings are organized with school leaders in DAR. The DAR leader gives instructions on school policies, events to be organized, different issues on teaching methods, initiatives to be undertaken on a national level etc. Usually, the communication is unilateral and the school leader does not have power of freedom in the implementation of such policies. Therefore, schools conduct strategies are harmonized with each other and with the system in whole. Other mechanisms applied to create a close relationship between the DAR and the schools and to monitor the policies' implementations are zone inspectors who cover 4-5 schools. They are part of DAR staff and are organized and directed under the directives of MASH.

The community is very passive on school matters. In general, when a school is not satisfactory to a parent, the solution usually is to change it for a new one. 


\section{Conclusions: Major Weaknesses and Major Strengths on School Leadership in Albania. What Have to Change?}

\subsection{Major strengths}

- A good tradition

- A general desire of parents to provide a good education for their children despite financial difficulties, that's mean more pressure to school for a good quality. A national survey conducted in Albania by ORT/USAID in the autumn of 1997 with 1500 residents with topic on life achievements preferences, showed that $30 \%$ of them (around 439) chose as first preference education.

- Constitutional obligation to implement international treaties ratified by the Republic of Albania (Article 4 of the Albanian Constitution: The Republic of Albania applies international law that is binding upon it; and under Article 116, ratified international treaties have priority over conflicting Albanian domestic laws).

- The new law "On pre-university education system", which improves the object of the law and improves the existents ambiguities in the professional status of a teacher and school leader by granting them a similar treatment with other professions.

\subsection{Major weaknesses}

- Lack of quality of external and internal accountability systems, have negatively affecting in completing the tasks related to the mandate of the Director, in assessing and reporting of achievement levels and measures when these levels are not satisfactory, to aware leadership for public accountability has taken.

- The intervention of politics, steadily, in the appointment and dismissal of school leadership, lack of transparency in the selection of candidates;

- Unstable school leadership, especially in big cities. The situation continues to be the same even nowadays, according to the data from a questionnaire, with 521 teachers (407 female, or $78.1 \%$ of the sample) of 20 public schools in Tirana, Shkodra, Kamëz and Elbasan, developed during February, 2015 - July, 2015 period. Teachers report their perceptions about the stability of leadership in their school. They accept to answer the question: During the period that you are teaching in this school, how often are changed the directors? They have to choose between: never, once, twice, and frequently. The chosen schools were at the top and the bottom of achievement for each city, in the same number: 10 with the good performance and 10 with weak performance. The profile of the responders, regarding the teaching years in the actual school, in a scale from 1 to 4 ( $1=1-5$ teaching yrs.; $2=6-10$ teaching yrs.; $3=11-20$ teaching yrs.; 4= over 21 teaching yrs.) was: mean $M=2.3647$, median $M d=2.00$ and Mode $M o=1.00$ (st. deviation 1.19672). The results of the self-report are in the Table III. The teachers, from both two types of schools performance, report the same: the directors in their schools are changed frequently.

Table III: The change frequency of the school director. The results of self-reports.

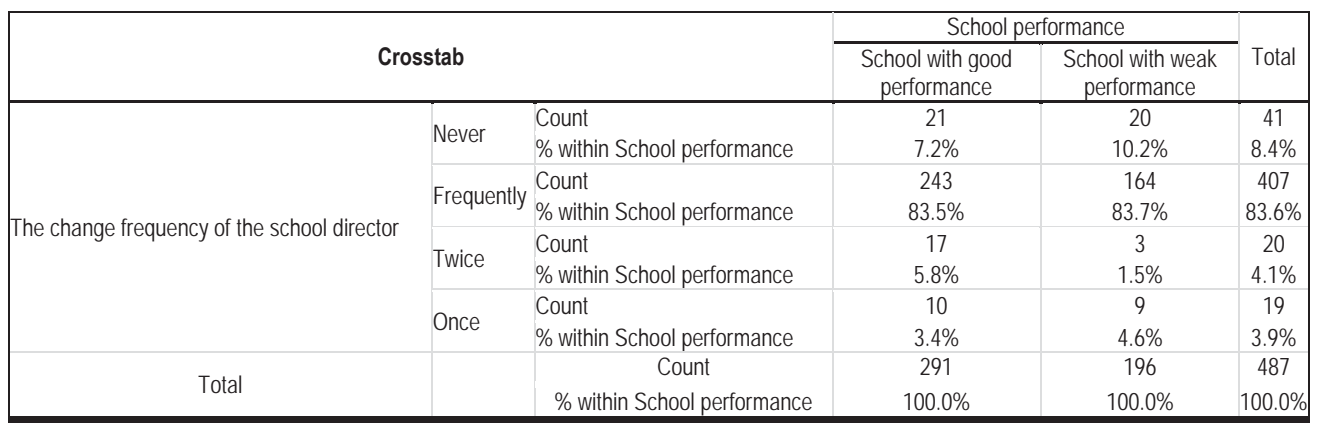

- The lack of professional networking leaders, formal and informal. 
- Inclusion of school outside actors and partners, in general, is ineffective and sporadic.

- Lack of space needed for individual leadership development.

- Lack of initiatives or strategies for leadership development, lack of serious investment in creating a new generation of leaders.

- Appointment at the position of school leader of unqualified people, without a preliminary preparation for direction.

- Lack of support for various forms of successful leadership.

Nowadays, Albania has passed a new law, Nr. 69/2012, in pre-university educational system. In the new law, there are a lot of differences regarding the leadership, but the situation is almost the same. The current changes, as follows, are proposed which have to be made in relation to school leaders:

$\checkmark$ a clear list of a school leader's powers and competences;

$\checkmark$ applying, in practice, with professionalism and out of any political influence, of selection criteria for the school leader;

$\checkmark$ a road-map to be followed so as to obtain and maintain such position.

\section{References}

Elmore R. F. (2004). School Reform From The Inside Out: Policy, Practice, And Performance. Cambridge, Massachusetts: Harvard Education Press.

Johnson, R. (1976). Teacher collaboration, principal influence, and decision making in elementary schools. Technical report, Stanford Center for Research and Development in Teaching. Retrieved in: http://files.eric.ed.gov/fulltext/ED126083.pdf

Liebermann A. \& Miller L. (1999). Teachers: Transforming their World and Their Work. New York: Teachers College Press.

Ligji nr. 7952, dt. 21.06.1995, ndryshuar me ligjin nr. 8387, datë 30.7.1998, "Për disa ndryshime në ligjin nr.7952", dt. 21.06.1995 "Për sistemin parauniversitar shqiptar", në mbështetje të nenit 16, të ligjit nr. 7491, datë 29.4.1991 "Për dispozitat kryesore kushtetuese", "Për sistemin arsimor parauniversitar", ndryshuar me ligjin nr. 9903, datë 17.4.2008, "Për një ndryshim dhe shtesë në ligjin nr.7952", datë 21.6.1995, "Për sistemin arsimor parauniversitar", të ndryshuar, në mbështetje të neneve 78 dhe 83 pika 1 të Kushtetutës.

MASH. (2009). Normat e punës mësimore në arsimin parauniversitar dhe standarde të lidhura me to. Udhëzim i ministrit të Arsimit dhe të Shkencës, Myqerem Tafaj, hyrë në fuqi, duke filluar nga semestri i dytë i vitit shkollor 2009-2010.

Payne Ch. M. (2011). So much reform, so littlechange. The persistence of failure in Urban Schools. Cambridge, Massachusetts: Harvard Education Press.

Pierce, M. \& Stapleton, D. (2002). The 21St-Century Principal: Current Issues in Leadership and Policy. Cambridge, Massachusetts: Harvard Education Press. 
